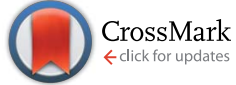

Cite this: RSC Adv., 2015, 5, 3435
Received 25th September 2014 Accepted 4th December 2014

DOI: 10.1039/c4ra10923f

www.rsc.org/advances

\title{
A push-pull organic semiconductor with efficient intramolecular charge transfer for solution- processed small molecule solar cells
}

\author{
Yu Jin Kim, ${ }^{a}$ Gi Back Lee, ${ }^{c}$ Chan Woo Jeon, ${ }^{b}$ Yun-Hi Kim, ${ }^{\star b}$ Dae Sung Chung ${ }^{\star d}$ \\ and Chan Eon Park*a
}

\begin{abstract}
A new push-pull organic semiconductor, DMF-BP-T-MMN, containing a functionalized amine donor and a methylene malononitrile (MMN) acceptor has been designed and synthesized for use in solutionprocessable small molecule solar cells. This material exhibits superior intramolecular charge transfer from the functionalized amine group to $M M N$, which produces an electron-rich MMN group that facilitates electron transfer into the active layer constituent phenyl- $\mathrm{C}_{71}$-butyric acid methyl ester in a solar cell. As a result, DMF-BP-T-MMN was found to exhibit excellent p-type semiconductor performance in an optimized organic solar cell: a power conversion efficiency of $3.40 \%$ with a high photocurrent density of $8.2 \mathrm{~mA} \mathrm{~cm}^{-2}$.
\end{abstract}

\section{Introduction}

In recent years, polymer solar cells (PSCs) containing a bulk heterojunction (BHJ) layer have attracted significant attention because they can be fabricated on flexible and light-weight substrates using high-throughput printing techniques and thus have the potential to provide low-cost solar electricity. ${ }^{1-3}$ Power conversion efficiencies (PCEs) above 10\% have been achieved due to significant improvements in active material design, device structure, device fabrication techniques, morphology control, and characterization methods, etc. ${ }^{\mathbf{4 - 6}}$ However, PSCs continue to be affected by the low reproducibility of certain characteristics (for example, the weight-average molecular weight and polydispersity index of the polymer) and the difficulties of purification. ${ }^{7,8}$

Solution-processed small molecule solar cells (SMSCs) have the advantages over PSCs of high purity as well as well-defined structure and molecular weight without batch-to-batch variation, and so have received more and more attention. ${ }^{9-12}$ Significant progress in the development of small molecule organic solar cells has recently been made and PCEs of $8-9 \%$ have been achieved. ${ }^{\mathbf{1 3 4} \mathbf{1 4}}$ However, their efficiency is typically lower than

${ }^{a}$ POSTECH Organic Electronics Laboratory, Department of Chemical Engineering, Pohang University of Science and Technology, Pohang, 790-784, Republic of Korea. E-mail: cep@postech.ac.kr

${ }^{b}$ Department of Chemistry \& ERI, Gyeongsang National University, Jin-ju, 660-701, Republic of Korea. E-mail: ykim@gnu.ac.kr

${ }^{c}$ School of Materials Science \& Engineering and Research Institute for Green Energy Convergence Technology (REGET), Gyeongsang National University, Jin-ju, 660-701, Republic of Korea

${ }^{d}$ School of Chemical Engineering and Material Science Chung-Ang University, Seoul, 156-756, Republic of Korea. E-mail: dchung@cau.ac.kr that of their polymer counterparts. ${ }^{15}$ In order to improve SMSC performance and take full advantage of the properties of small molecules, further systematic research is required. In particular, improvements in active materials, especially in the donor materials, are vital to the production of high PCE SMSCs.

Some structural cores are commonly present in organic semiconductors for SMSCs, such as oligothiophene, bridged dithiophene, benzothiadiazole, squaraine, and diketopyrrolopyrrole, which have been inspired by the low band gap semiconducting materials ${ }^{\mathbf{1 6 - 1 8}}$ and push-pull molecular structures ${ }^{\mathbf{1 9 - 2 1}}$ used in nonlinear optics because of their superior optoelectronic properties. A push-pull structure enables efficient intramolecular charge transfer (ICT), which gives the chromophore the required molar absorptivity. ${ }^{22}$ In addition, the presence of an electron donor unit, such as an amine substituted with a fluorene group, can stabilize hole-exciton separation and improve the transport properties of the hole carrier. $^{23-25}$

With this strategy in mind, we have designed and synthesized a new small molecule with a push-pull structure, 2-[\{5"[biphenyl-4-yl-9,9-dimethyl-9H-fluorene-3yl]-amino\}-[2,2' , $\left.^{\prime}, 2^{\prime \prime}\right]$ terthiophen-5-ylmethylene]-malononitrile (DMF-BP-T-MMN). This compound consists of an amine donor, functionalized with fluorene and a bi-phenyl group, and a methylene malononitrile acceptor, which are linked by a terthiophene $\pi$-conjugation bridge. As expected, this material was found to exhibit superior ICT to the MMN acceptor through the $\pi$-conjugated terthiophene bridge, which produces an electronrich $\mathrm{MMN}$ terminal unit that facilitates electron transfer into $\mathrm{PC}_{71} \mathrm{BM}$. Small molecule $\mathrm{BHJ}$ devices were fabricated by using this compound as the donor and $\mathrm{PC}_{71} \mathrm{BM}$ as the acceptor. A PCE 
of $3.40 \%$ with a high photocurrent density of $8.2 \mathrm{~mA} \mathrm{~cm}^{-2}$ was achieved in an optimized device.

\section{Results and discussion}

\section{Synthesis and thermal properties}

The synthetic route for DMF-BP-T-MMN is shown in Scheme 1. DMF-BP-T-MMN was synthesized by performing BuchwaldHartwig $N$-arylation, lithiation, and a Suzuki coupling reaction. The chemical structure of the synthesized compound was confirmed with ${ }^{1} \mathrm{H}-\mathrm{NMR},{ }^{13} \mathrm{C}-\mathrm{NMR}$, and mass spectroscopy. This small molecule is readily dissolved in common organic solvents, such as dichlorobenzene, chlorobenzene, chloroform, and toluene, owing to its alkyl-substituted fluorene moiety. The thermal stability of DMF-BP-T-MMN was investigated with thermogravimetric analysis (TGA) (Fig. 1a) and differential scanning calorimetry (DSC) (Fig. 1b) at a heating rate of $10{ }^{\circ} \mathrm{C}$ $\min ^{-1}$. The TGA profile shows that the onset decomposition temperature ( $T_{\mathrm{d}}$, at $5 \%$ weight loss) of DMF-BP-T-MMN is 434 ${ }^{\circ} \mathrm{C}$, which indicates that the compound will be fairly stable in long-term photovoltaic applications. ${ }^{26}$ No endothermic or exothermic behavior was found between $25^{\circ} \mathrm{C}$ and $225^{\circ} \mathrm{C}$ in the DSC results.

\section{Optical properties}

The normalized absorption spectra of the small molecule in chloroform solution and in the thin film state are shown in Fig. 2a, and the corresponding absorption data are listed in Table 1. The DMF-BP-T-MMN molecule exhibits strong absorption in the wavelength range $300-800 \mathrm{~nm}$ (the visible region) and standard dual absorption profiles due to its ICT band are evident for both the thin film and solution states. The maximum absorption peaks $\left(\lambda_{\max }\right)$ of the compound in chloroform are located at 356 and $551 \mathrm{~nm}$. The absorption band at longer wavelengths $(500-600 \mathrm{~nm})$ originates from $\mathrm{ICT}^{27}$ and the absorption band at $350-450 \mathrm{~nm}$ is due to $\pi-\pi^{*}$ transitions. ${ }^{28} \mathrm{In}$ the thin film state, the absorption band of DMF-BP-T-MMN is stronger and red-shifted compared to that of the solution, which indicates that there are increased $\pi-\pi^{*}$ intermolecular interactions in the solid state. ${ }^{29}$ The optical band gap $\left(E_{\mathrm{g}}^{\text {opt }}\right)$ calculated from the film absorption edge is $1.74 \mathrm{eV}$.

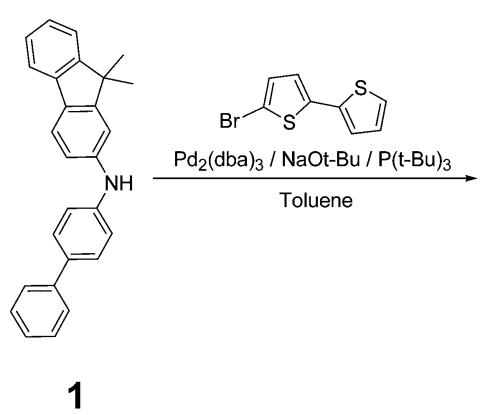

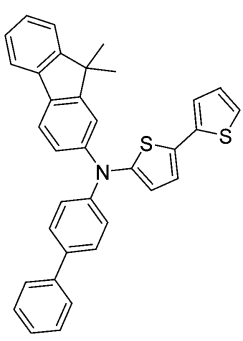

2

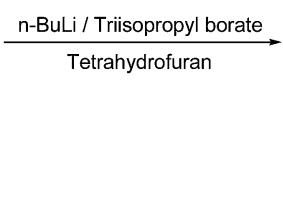

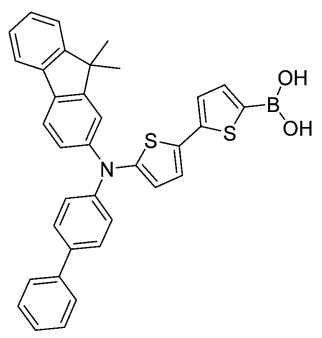

3
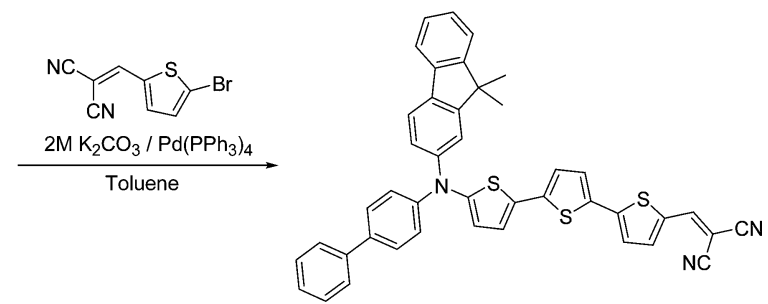

Scheme 1 Synthetic route for DMF-BP-T-MMN.
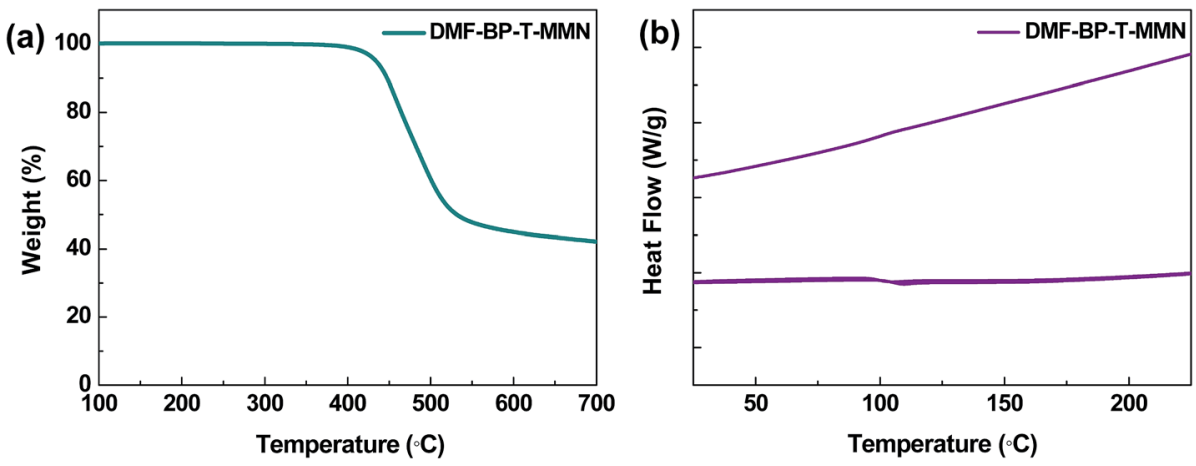

Fig. 1 TGA plot for DMF-BP-T-MMN (a) and DSC curves for DMF-BP-T-MMN (b) recorded at a heating rate of $10^{\circ} \mathrm{C} \mathrm{min}{ }^{-1}$. 

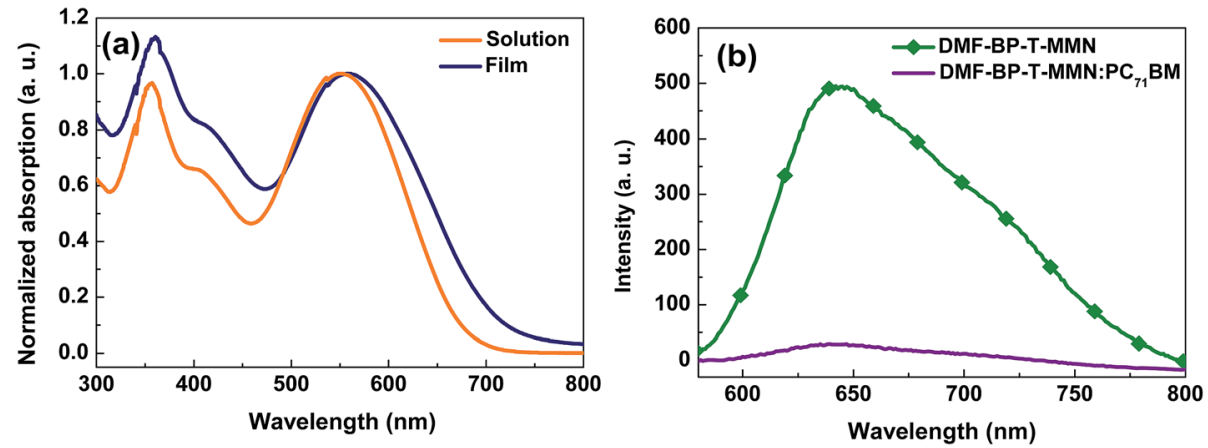

Fig. 2 (a) Normalized UV-vis absorption spectra of DMF-BP-T-MMN in chloroform and in the thin film state at room temperature; (b) Photoluminescence spectra of DMF-BP-T-MMN and a DMF-BP-T-MMN : PC ${ }_{71} B M$ blend film.

Table 1 Optical and electrochemical characteristics of DMF-BP-T-MMN

\begin{tabular}{|c|c|c|c|c|c|c|c|c|}
\hline Small molecule & $\lambda_{\max }(\mathrm{nm})$ solution & $\lambda_{\max }(\mathrm{nm})$ film & $\lambda_{\text {onset }}(\mathrm{nm})$ film & $E_{\mathrm{g}}^{\mathrm{opt}}(\mathrm{eV})^{a}$ & $E_{\text {onset }}^{\text {ox }}(\mathrm{eV})$ & $E_{\text {onset }}^{\text {red }}(\mathrm{eV})$ & $E_{\text {Номо }}(\mathrm{eV})$ & $E_{\text {LUMO }}(\mathrm{eV})$ \\
\hline DMF-BP-T-MMN & 356,551 & 360,560 & 713 & 1.74 & 1.45 & -0.74 & -5.81 & -3.62 \\
\hline
\end{tabular}

The PL spectra of a spin-cast film of pure DMF-BP-T-MMN and of a $1: 4(\mathrm{w} / \mathrm{w})$ blend of the small molecule and $\mathrm{PC}_{71} \mathrm{BM}$ were examined with the aim of assessing the charge transfer properties of DMF-BP-T-MMN (Fig. 2b). The PL spectrum of DMF-BP-T-MMN contains a strong PL emission band with a maximum at $644 \mathrm{~nm}$. Upon the addition of $\mathrm{PC}_{71} \mathrm{BM}$, the emission band is almost completely quenched, which suggests that there is ultrafast and efficient photoinduced charge transfer from the small molecule to PCBM. ${ }^{30}$

\section{Electrochemical properties}

In order to investigate the electrochemical properties of the synthesized compound, cyclic voltammetry (CV) measurements were conducted on a DMF-BP-T-MMN film on a Pt electrode at a scan rate of $50 \mathrm{mV} \mathrm{s}^{-1}$. The highest occupied molecular orbital (HOMO) level, the lowest unoccupied molecular orbital (LUMO) level, and the electrochemical band gap of DMF-BP-T-MMN were calculated from the onset oxidation potential ( $\left.E_{\text {onset }}^{\text {ox }}\right)$ and the onset reduction potential ( $\left.E_{\text {onset }}^{\text {red }}\right)$ according to the following equations:

$$
\begin{aligned}
& E_{\mathrm{HOMO}}=-\left(E_{\text {onset }}^{\text {ox }}-\text { ferrocene }_{\text {onset }}\right)-4.8 \mathrm{eV} \\
& E_{\mathrm{LUMO}}=-\left(E_{\text {onset }}^{\text {red }}-\text { ferrocene }_{\text {onset }}\right)-4.8 \mathrm{eV}
\end{aligned}
$$

where $E_{\text {onset }}^{\text {ox }}$ and $E_{\text {onset }}^{\text {red }}$ were measured relative to $\mathrm{Ag} / \mathrm{AgCl}$, and ferrocene $_{\text {onset }}$ is the reference onset oxidation potential of ferrocene $(0.44 \mathrm{eV}) .{ }^{31}$

The CV curve of the small molecule is shown in Fig. 3a and the corresponding electrochemical data are summarized in Table 1 . The $E_{\text {onset }}^{\text {ox }}$ and $E_{\text {onset }}^{\text {red }}$ of DMF-BP-T-MMN were found to be 1.45 and $-0.74 \mathrm{~V}$ vs. $\mathrm{Ag} / \mathrm{AgCl}$ respectively, and the corresponding HOMO and LUMO energy levels were estimated to be $-5.81 \mathrm{eV}$ and $-3.62 \mathrm{eV}$. These results indicate that DMF-BP-TMMN has the appropriate energy levels to act as a donor in
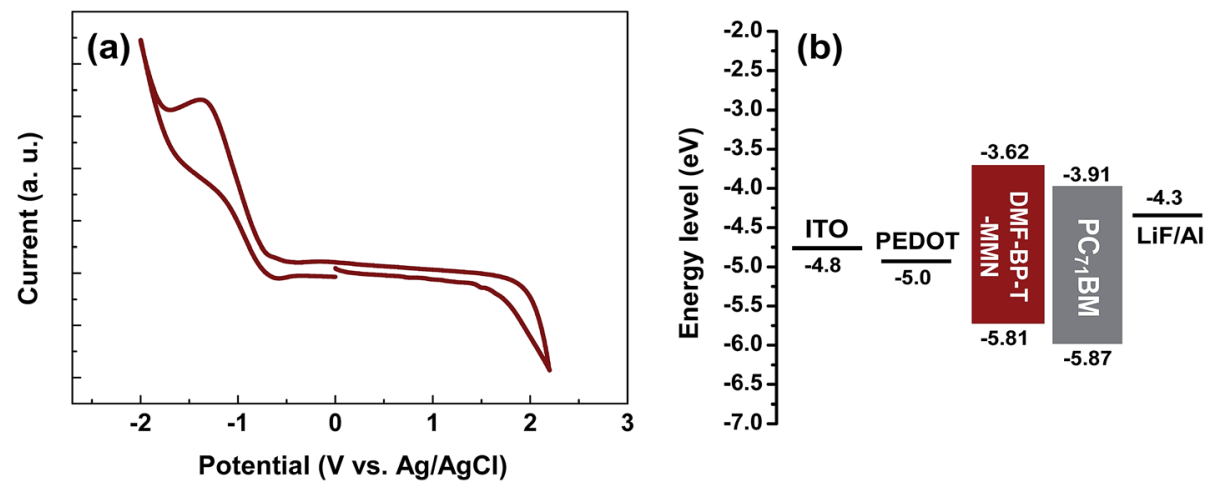

Fig. 3 (a) Cyclic voltammogram of DMF-BP-T-MMN, and (b) energy level diagram for the component materials of the devices. 
solution-processable organic solar cells with $\mathrm{PC}_{71} \mathrm{BM}$ as the acceptor (see Fig. 3b).

To investigate the oxidative and reductive properties of DMFBP-T-MMN, its geometry and electronic structure were calculated with density functional theory (DFT). Becke's three parameter gradient corrected functional (B3LYP) with a polarized 6-31 $\mathrm{G}^{* *}$ basis was used for full geometry optimization. The geometries and the HOMO and LUMO surface plots of the ground-state optimized structure are shown in Fig. 4. The orbital density of the HOMO is located predominantly on the functionalized amine donor, whereas the orbital density of the LUMO has methylene malononitrile (MMN) character. These calculations demonstrate that ICT can occur effectively from the electron-donating amine unit to the MMN acceptor in DMF-BP-
T-MMN when excited by light energy. ${ }^{32}$ The calculated HOMO and LUMO energies of the ground-state optimized geometry of DMF-BP-T-MMN are $-5.04 \mathrm{eV}$ and $-2.96 \mathrm{eV}$ respectively, and the band gap was determined to be $2.08 \mathrm{eV}$.

\section{Solar cell device performance}

Small molecule BHJ solar cells were fabricated with DMF-BP-TMMN as the donor material and $\mathrm{PC}_{71} \mathrm{BM}$ as the acceptor material by using a conventional solution spin-coating process. The device structure is ITO/PEDOT : PSS/photoactive layer/LiF/ $\mathrm{Al}$ (see Fig. 5a). Device optimization was conducted by varying the donor $v s$. acceptor weight ratio and the total solution concentration. The current density voltage $(J-V)$ characteristics
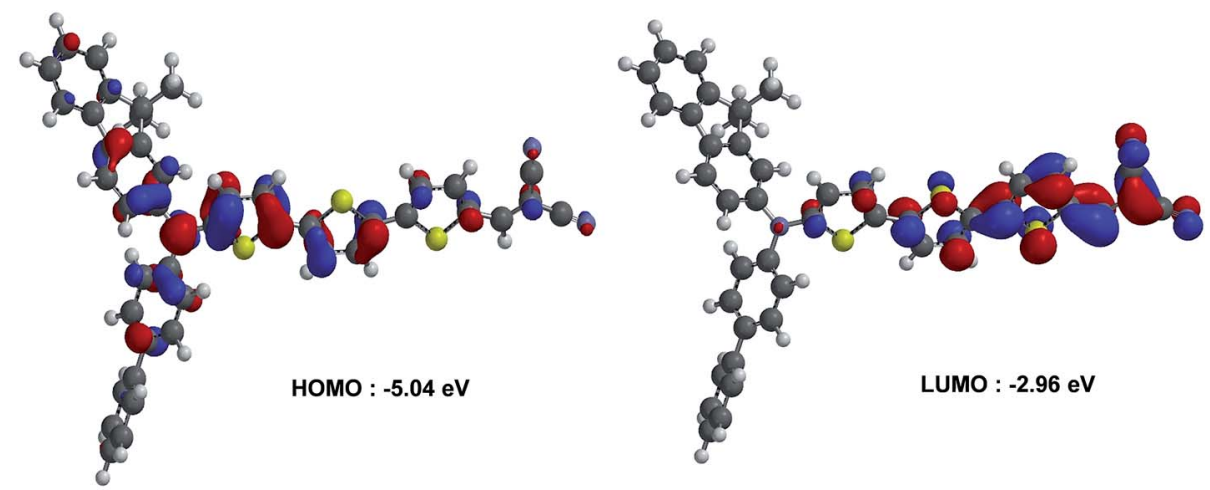

Fig. 4 Isodensity surface plots of DMF-BP-T-MMN calculated with DFT.
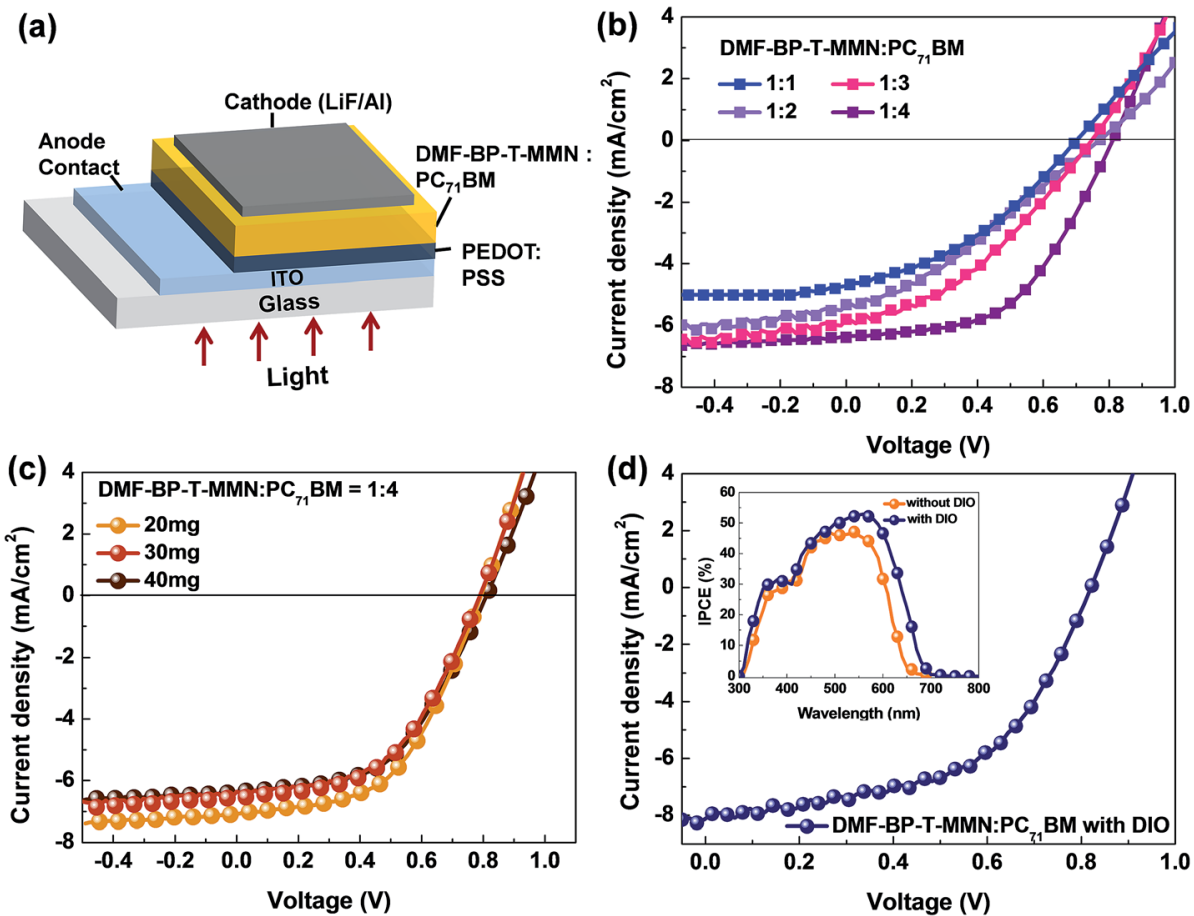

Fig. 5 Schematic diagram of the photovoltaic cell. (b), (c) $J-V$ curves for various DMF-BP-T-MMN : PC ${ }_{71} B M$ blend ratios and solution concentrations respectively. (d) $J-V$ curve obtained from the best-performing device processed in the presence of 2 vol\% DIO. The inset shows the IPCE spectra of the devices processed with and without the DIO additive. 
Table 2 Summary of the parameters of the devices containing various DMF-BP-T-MMN : PC ${ }_{71}$ BM compositions blended in chloroform

\begin{tabular}{llllll}
\hline Small molecule: PCBM & $\begin{array}{l}\text { Blend } \\
\text { ratios }\end{array}$ & $\begin{array}{l}V_{\mathrm{oc}} \\
(\mathrm{V})\end{array}$ & $\begin{array}{l}J_{\mathrm{sc}} \\
\left(\mathrm{mA} \mathrm{cm}^{-2}\right)\end{array}$ & $\begin{array}{l}\mathrm{FF} \\
(\%)\end{array}$ & $\begin{array}{l}\text { PCE } \\
(\%)\end{array}$ \\
\hline DMF-BP-T- & $1: 1$ & 0.74 & 4.7 & 28.4 & 0.98 \\
MMN : PC & & & & & \\
& $1: 2$ & 0.77 & 5.3 & 31.8 & 1.33 \\
& $1: 3$ & 0.75 & 5.9 & 39.5 & 1.74 \\
& $1: 4$ & 0.79 & 6.3 & 43.7 & 2.17
\end{tabular}

Table 3 Photovoltaic data for the DMF-BP-T-MMN:PC ${ }_{71} B M$ $(1: 4 \mathrm{w} / \mathrm{w})$ devices for various total concentrations

\begin{tabular}{|c|c|c|c|c|c|}
\hline $\begin{array}{l}\text { Small molecule: } \\
\text { PCBM }\end{array}$ & $\begin{array}{l}\text { Total } \\
\text { concentration } \\
\left(\mathrm{mg} \mathrm{mL}^{-1}\right)\end{array}$ & $\begin{array}{l}V_{\mathrm{oc}} \\
(\mathrm{V})\end{array}$ & $\begin{array}{l}J_{\mathrm{sc}} \\
(\mathrm{mA} \%)\end{array}$ & $\begin{array}{l}\mathrm{FF} \\
(\%)\end{array}$ & $\begin{array}{l}\text { PCE } \\
(\%)\end{array}$ \\
\hline DMF-BP-T- & 20 & 0.79 & 7.1 & 52.0 & 2.91 \\
\hline \multirow[t]{2}{*}{$\mathbf{M M N}: \mathrm{PC}_{71} \mathrm{BM}$} & 30 & 0.78 & 6.7 & 50.8 & 2.65 \\
\hline & 40 & 0.79 & 6.3 & 43.7 & 2.17 \\
\hline
\end{tabular}

under one sun (simulated AM1.5 $\mathrm{G}$ irradiation at $100 \mathrm{~mW} \mathrm{~cm}{ }^{-2}$ ) are shown in Fig. $5 \mathrm{~b}$ and $\mathrm{c}$ and the photovoltaic parameters are presented in Table 2 and 3. Optimal fabrication conditions were achieved with a DMF-BP-T-MMN : PC $_{71}$ BM ratio of $1: 4(\mathrm{w} / \mathrm{w})$; this device was found to exhibit an open-circuit voltage $\left(V_{\text {oc }}\right)$ of $0.79 \mathrm{~V}$, a short-circuit current $\left(J_{\mathrm{sc}}\right)$ of $6.3 \mathrm{~mA} \mathrm{~cm}^{-2}$, a fill factor (FF) of $43.7 \%$, and a PCE of $2.17 \%$ (Fig. $5 \mathrm{~b}$ ). From the photovoltaic measurement, with the decreasing weight ratio of PCBM, $J_{\mathrm{sc}}$ and FF showed a gradually reducing trend; a possible explanation for this phenomenon may be from highly phase separated film with quite much aggregation, as shown in the morphology section (see Fig. 6). After optimization with respect to the material concentration, a higher PCE of $2.91 \%$ was obtained at a concentration of $20 \mathrm{mg} \mathrm{mL}^{-1}$. Therefore, a $1: 4$ $(\mathrm{w} / \mathrm{w})$ blend composition at a solution concentration of $20 \mathrm{mg}$ $\mathrm{mL}^{-1}$ was used in further device optimization with respect to the use of a processing additive, 1,8-diiodooctane (DIO). As mentioned above, to further improve the photovoltaic performance of DMF-BP-T-MMN : $\mathrm{PC}_{71} \mathrm{BM}$ devices, the DIO additive is used in the active layer. The following DIO volume fractions were used: $0.5,1,2$ and $4 \%$. The device performance is summarized in Table 3. We found that the presence of the DIO additive leads to an improvement in the device performance.
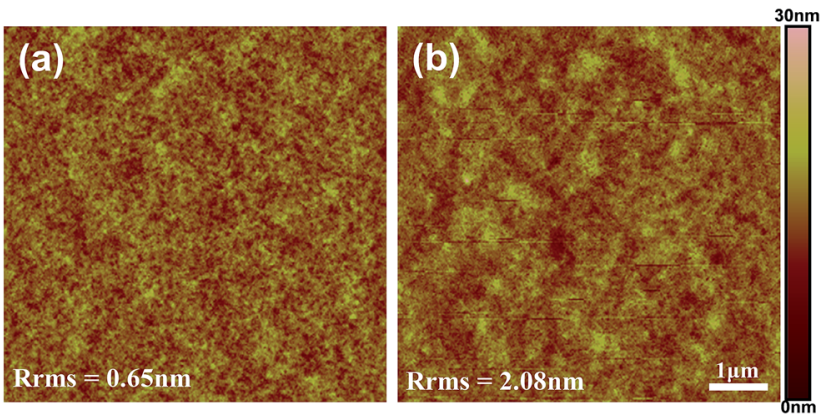

Fig. 7 Tapping-mode AFM surface topographies of DMF-BP-TMMN : $P C_{71} B M(1: 4)$ films processed without (a) and with (b) 2 vol\% DIO.

The PCE is elevated to $3.40 \%$, with a $V_{\mathrm{oc}}$ of $0.78 \mathrm{~V}, \mathrm{a} J_{\mathrm{sc}}$ of $8.2 \mathrm{~mA}$ $\mathrm{cm}^{-2}$, and a $\mathrm{FF}$ of $53.1 \%$, which is the best performance for the DMF-BP-T-MMN : PC $_{71} \mathrm{BM}$ device processed by with 2 vol\% DIO. This improvement in PCE is mainly due to the improvement in $J_{\mathrm{sc}}$ (from 7.1 to $8.2 \mathrm{~mW} \mathrm{~cm}^{-2}$ ) and changes in properties such as the film morphology and the hole mobility, as discussed below. $J_{\text {sc }}$ is strongly dependent on the photo-response (the conversion of input photons to photocurrent). ${ }^{33}$ The photoresponse of DMF-BP-T-MMN : $\mathrm{PC}_{71} \mathrm{BM}$ processed in the presence of DIO is above $52 \%$ at $560 \mathrm{~nm}$, whereas that of DMF-BP-TMMN : $\mathrm{PC}_{71} \mathrm{BM}$ processed in the absence of this additive is above $46 \%$ at $534 \mathrm{~nm}$ (Fig. $5 \mathrm{~d}$ ). The higher EQE values of the DMF-BP-T-MMN : $\mathrm{PC}_{71} \mathrm{BM}$ cells processed in the presence of DIO are attributed to the greater conversion of input photons to photocurrent at all absorption wavelengths, as is consistent with the higher circuit current observed..$^{34}$

\section{Film morphology}

The performances of solar cell devices are closely associated with the nano-morphologies of their active layers, so we investigated the film morphologies of the DMF-BP-T-MMN : PC $_{71} \mathrm{BM}$ blend films $(1: 4, \mathrm{w} / \mathrm{w})$ by performing tapping mode atomic force microscopy (AFM). Fig. 7 shows AFM height images of the blend films processed with and without 2 vol\% DIO. The blend film in (a) has a relatively homogeneous and flat surface with a root-mean-squared (RMS) roughness of $0.65 \mathrm{~nm}$. In contrast, the spin-coated blend film processed with DIO in (b) has slightly more aggregated domains and a phase-separated surface with a larger RMS roughness of $2.08 \mathrm{~nm}$. The aggregated domains are
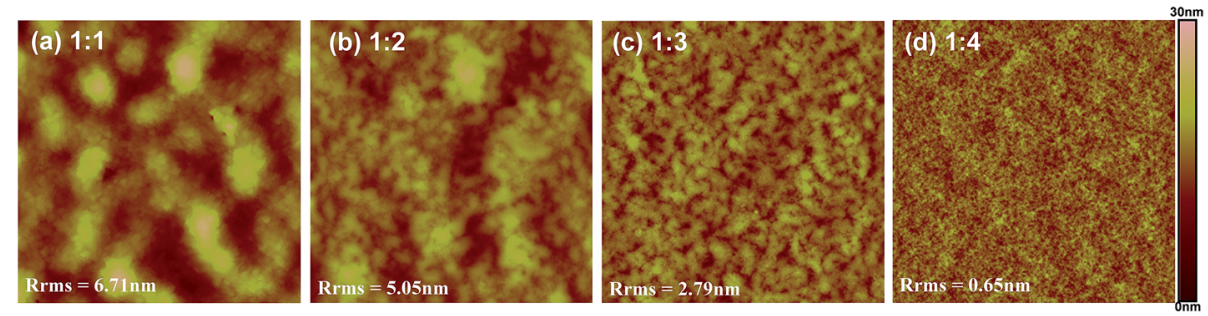

Fig. 6 AFM height images for DMF-BP-T-MMN : PC 71 BM blend films with different weight ratios spin coated from chloroform: (a) $1: 1$, (b) $1: 2$, (c) $1: 3$, and (d) $1: 4$. 
most likely to have originated from enhancements in the intermolecular interactions of DMF-BP-T-MMN. ${ }^{35}$ Moreover, the higher roughness of DMF-BP-T-MMN : $\mathrm{PC}_{71} \mathrm{BM}$ processed with 2 vol\% DIO means that this film will exhibit reduced internal resistance and more efficient charge separation in SMSCs. ${ }^{36} \mathrm{~A}$ higher surface roughness also leads to increased internal light scattering and enhanced light absorption. ${ }^{37}$ All of these characteristics will produce a device with a higher $J_{\text {sc }}$ value and better efficiency than that exhibited by the DMF-BP-TMMN : PC $_{71} \mathrm{BM}$ device processed in the absence of the additive (Table 4).

\section{Hole mobility}

To investigate space-charge effects, the hole mobilities of the DMF-BP-T-MMN : PC $_{71} \mathrm{BM}$ blend films were extracted from the space-charge limited current (SCLC) $J-V$ characteristics obtained in the dark for hole-only devices. Fig. 8 shows the darkcurrent characteristics of the ITO/PEDOT : PSS/DMF-BP-TMMN : $\mathrm{PC}_{71} \mathrm{BM}(1: 4) / \mathrm{Au}$ devices prepared with or without DIO as functions of the bias corrected for the built-in voltage determined from the difference between the work functions of $\mathrm{Au}$ and PEDOT : PSS-coated ITO. As shown in Fig. 8, the average hole mobilities of the blend films processed without and with 2 vol\% DIO were found to be $2.17 \times 10^{-6} \mathrm{~cm}^{2} \mathrm{~V}^{-1} \mathrm{~s}^{-1}$ and $8.63 \times$ $10^{-6} \mathrm{~cm}^{2} \mathrm{~V}^{-1} \mathrm{~s}^{-1}$ respectively, which is consistent with the $J_{\mathrm{sc}}$ values of their solar cells. The hole mobility of the device processed with DIO is higher than that of the device processed without DIO; this difference is closely related to the

Table 4 Device performance of various amounts of DIO additive in the DMF-BP-T-MMN : PC ${ }_{71} B M(1: 4 \mathrm{w} / \mathrm{w})$ cell

\begin{tabular}{llllll}
\hline $\begin{array}{l}\text { Small molecule: } \\
\text { PCBM }\end{array}$ & $\begin{array}{l}\text { DIO additive } \\
{[\mathrm{vol} \%]}\end{array}$ & $\begin{array}{l}V_{\mathrm{oc}} \\
(\mathrm{V})\end{array}$ & $\begin{array}{l}J_{\mathrm{sc}} \\
\left.(\mathrm{mA} \mathrm{cm})^{-2}\right)\end{array}$ & $\begin{array}{l}\mathrm{FF} \\
(\%)\end{array}$ & $\begin{array}{l}\text { PCE } \\
(\%)\end{array}$ \\
\hline DMF-BP-T-MMN : & 0.5 & 0.70 & 3.7 & 38.2 & 0.98 \\
PC $_{71} \mathrm{BM}$ & 1 & 0.76 & 6.1 & 50.9 & 2.36 \\
& 2 & 0.78 & 8.2 & 53.1 & 3.40 \\
& 4 & 0.72 & 4.4 & 42.8 & 1.35
\end{tabular}

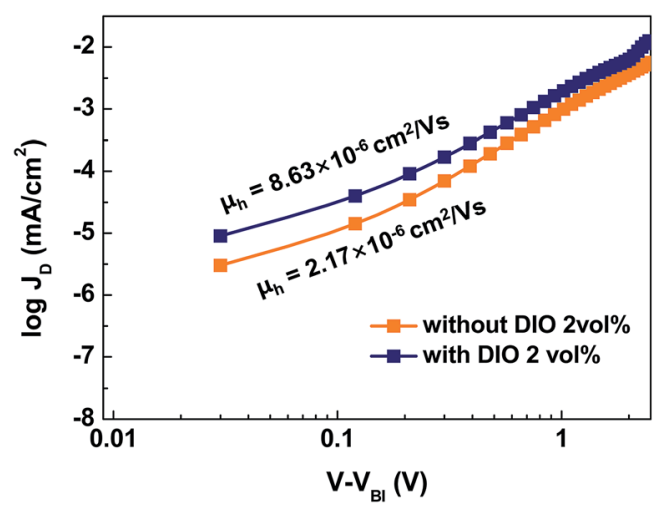

Fig. 8 Hole mobilities of DMF-BP-T-MMN : $\mathrm{CC}_{71} \mathrm{BM}$ cast from bare solvent and from solvent containing 2 vol\% DIO. intermolecular packing interaction as well as to the stability of the charge-exciton separation, which both improve the transport properties of the hole carrier. ${ }^{38}$

\section{Conclusion}

We have synthesized a small molecule, DMF-BP-T-MMN, which contains a functionalized amine donor and a methylene malononitrile (MMN) acceptor, and investigated its photovoltaic characteristics. This new material exhibits superior intramolecular charge transfer from the functionalized amine group to MMN through a $\pi$-conjugated terthiophene bridge, which creates an electron-rich MMN acceptor. This charge transfer process facilitates electron transfer into $\mathrm{PC}_{71} \mathrm{BM}$, which results in excellent hole-transport properties. SMSCs based on this efficient p-type semiconductor were found to exhibit a PCE of $3.40 \%$ after optimization. The results of the molecular engineering approach of this study provide a useful guide for the development of new materials for solution-processed SMSCs.

\section{Experimental}

\section{Materials}

All chemical reagents were purchased from Aldrich and TCI. The catalysts used in the coupling reactions were purchased from Umicore. The other materials were of common commercial level and used as received. All solvents were purified prior to use.

\section{Syntheses of materials}

Synthesis of $N$-([1,1'-biphenyl]-4 yl)-9,9-dimethyl-9H-fluoren2-amine (1). Compound (1) was prepared according to an established method. ${ }^{39}$ Yield: $9.50 \mathrm{~g}(71.9 \%) .{ }^{1} \mathrm{H}$ NMR $(300 \mathrm{MHz}$, $\left.\mathrm{CD}_{2} \mathrm{Cl}_{2}\right)[\mathrm{ppm}] \delta=7.72-7.60(\mathrm{~m}, 6 \mathrm{H}), 7.51-7.46(\mathrm{~m}, 3 \mathrm{H}), 7.40-$ 7.10 (br, 7H), 6.04 (br, 1H), 1.54 (s, 6H).

Synthesis of $\mathrm{N}$-([1,1'-biphenyl]-4 yl)- $\mathrm{N}$-(9,9-dimethyl-9H-fluoren-2-yl)-[2,2'-bithiophen]-5-amine (2). $N$-([1,1'-biphenyl]-4 yl)9,9-dimethyl-9H-fluoren-2-amine (10.00 g, $27.66 \mathrm{mmol})$, sodium tert-butoxide (3.19 g, $33.19 \mathrm{mmol})$, 5-bromo-2,2'-bithiophene (8.14 g, $33.19 \mathrm{mmol})$, and $\operatorname{Pd}_{2}(\mathrm{dba})_{3}(1.26 \mathrm{~g}, 1.38 \mathrm{mmol})$ were dissolved in anhydrous toluene $(150 \mathrm{~mL})$ under a nitrogen atmosphere. One portion of $\mathrm{P}(t-\mathrm{Bu})_{3}(1.38 \mathrm{~mL}, 1.38 \mathrm{mmol}, 1.0 \mathrm{M}$ in toluene) was added. The solution mixture was slowly heated to reflux, and stirred for $12 \mathrm{~h}$. After cooling, the reaction mixture was extracted with dichloromethane; the combined organic layer was then washed with water and brine, and dried with $\mathrm{MgSO}_{4}$. The residue was chromatographed over silica gel by using dichloromethane/hexane $(\mathrm{v} / \mathrm{v}=1: 10)$ as the eluent. Recrystallization from ethanol afforded a yellow product. Yield: $9.10 \mathrm{~g}(62.7 \%) .{ }^{1} \mathrm{H} \mathrm{NMR}\left(300 \mathrm{MHz}, \mathrm{CD}_{2} \mathrm{Cl}_{2}\right)[\mathrm{ppm}] \delta=7.72-7.56$ $(\mathrm{m}, 6 \mathrm{H}), 7.49-7.44(\mathrm{~m}, 3 \mathrm{H}), 7.39-7.28(\mathrm{~m}, 6 \mathrm{H}), 7.24-7.19(\mathrm{~m}$, $2 \mathrm{H}), 7.13(\mathrm{dd}, 1 \mathrm{H}), 7.05(\mathrm{~m}, 2 \mathrm{H}), 6.72(\mathrm{~d}, 1 \mathrm{H}), 1.47(\mathrm{~s}, 6 \mathrm{H}) .{ }^{13} \mathrm{C}$ NMR $\left(500 \mathrm{MHz}, \mathrm{CDCl}_{3}\right)[\mathrm{ppm}] \delta=155.16,153.66,150.50$, 147.23 , 146.84, 140.56, 138.81, 137.95, 135.63, 135.04, 131.42, $128.78,127.79,127.74,127.02$, 126.93, 126.73, 123.79, 122.90, 
122.51, 122.37, 122.31, 121.19, 120.65, 119.59, 117.72, 46.96, 27.11. MS (EI) $m / z=525(\mathrm{M}+)$.

Synthesis of ( $5^{\prime}-\left(\left[1,1^{\prime}\right.\right.$-biphenyl $]-4$ yl 9,9-dimethyl-9H-fluoren2-yl)amino)-[2,2'-bithiophen]-5 yl)boronic acid (3). $\quad N-\left(\left[1,1^{\prime}-\right.\right.$ biphenyl]-4 yl)- $N$-(9,9-dimethyl-9H-fluoren-2-yl)-[2,2'-bithiophen]-5amine (2) (3.00 g, $5.71 \mathrm{mmol})$ was dissolved in anhydrous tetrahydrofuran $(100 \mathrm{~mL})$ under a nitrogen atmosphere. The solution was cooled to $0{ }^{\circ} \mathrm{C}$, then $n$-BuLi $(2.5 \mathrm{M}$ in hexane, $2.51 \mathrm{~mL}, 6.28$ mmol) was added slowly and the reaction mixture was stirred for 2 h. Triisopropyl borate $(1.50 \mathrm{~g}, 7.99 \mathrm{mmol})$ was added at $0{ }^{\circ} \mathrm{C}$. After addition was completed, the reaction mixture was gradually warmed to room temperature and stirred overnight. $2 \mathrm{~N} \mathrm{HCl}$ was added to quench the reaction and then stirred for $1 \mathrm{~h}$. The reaction mixture was extracted with dichloromethane and the combined organic layer was washed with water and brine, then dried with $\mathrm{MgSO}_{4}$. The dichloromethane solution containing the product was reprecipitated in hexane and filtered out. The crude product was transferred to the next reaction step without further purification. Yield: $2.10 \mathrm{~g}(64.6 \%)$.

Synthesis of $2-\left(\left(5^{\prime \prime}-\left(\left[1,1^{\prime}\right.\right.\right.\right.$-biphenyl $]-4$ yl(9,9-dimethyl-9H-fluoren-2-yl)amino)-[2,2' $: 5^{\prime}, 2^{\prime \prime}$-terthiophen]-5 yl)methylene)malononitrile (DMF-BP-T-MMN). $2 \mathrm{M} \mathrm{K}_{2} \mathrm{CO}_{3}(6 \mathrm{~mL})$ was added to a solution of (5'-([1,1'-biphenyl]-4 yl(9,9-dimethyl-9H-fluoren-2-yl) amino)-[2,2'-bithiophen]-5 yl)boronic acid (3) (1.66 g, 2.92 $\mathrm{mmol})$ and 2-((5-bromothiophen-2-yl)methylene)malononitrile $(0.50 \mathrm{~g}, 2.09 \mathrm{mmol})$ in toluene $(50 \mathrm{~mL})$. The mixture was bubbled with nitrogen for $30 \mathrm{~min}$ and then $\mathrm{Pd}\left(\mathrm{PPh}_{3}\right)_{4}$ was added. The mixture was heated to $100{ }^{\circ} \mathrm{C}$ for $24 \mathrm{~h}$ under a nitrogen atmosphere. The mixture was washed with chloroform and water. After drying over anhydrous $\mathrm{MgSO}_{4}$, the solvent was evaporated. Purification was performed on a silica column with dichloromethane/hexane $(\mathrm{v} / \mathrm{v}=1: 5)$ as the eluent. The dichloromethane solution containing the product was reprecipitated in hexane and filtered out. Yield: $0.98 \mathrm{~g}(68.5 \%) .{ }^{1} \mathrm{H}$ NMR (300 MHz, $\left.\mathrm{CD}_{2} \mathrm{Cl}_{2}\right)[\mathrm{ppm}] \delta=7.81(\mathrm{~s}, 1 \mathrm{H}), 7.73-7.59(\mathrm{~m}$, 7H), 7.49-7.45 (m, 3H), 7.41-7.29 (m, 8H), 7.25 (dd, 1H), 7.14 (d, 1H), 7.09 (d, 1H). 6.69 (d, 1H). 1.48 (s, 6H). ${ }^{13} \mathrm{C} \mathrm{NMR} \mathrm{(500} \mathrm{MHz,}$ $\left.\mathrm{CDCl}_{3}\right)[\mathrm{ppm}] \delta=155.30,153.66,152.91,149.77,149.29,146.81$, 146.46, 141.48, 140.38, 140.09, 138.62, 136.37, 135.69, 133.15, 132.49, 128.81, 128.39, 128.23, 127.93, 127.08, 126.93, 126.75, 124.08, 124.02, 123.69, 123.01, 122.93, 122.54, 120.77, 119.69, 119.50, 118.27, 114.36, 113.55, 75.66, 46.99, 31.58, 27.08, 22.64, 14.09. MS (EI) $m / z=683(\mathrm{M}+)$.

\section{Instruments and measurements}

${ }^{1} \mathrm{H}-\mathrm{NMR}$ spectra were recorded with a Bruker Avance-300 spectrometer. ${ }^{13} \mathrm{C}-\mathrm{NMR}$ spectra were obtained by using a DRX-500 spectrometer. HRMS (EI) spectra were recorded by using a high resolution GC mass spectrometer with LabRAM HR800 UV. Mass (MALDI-TOF/TOF) spectra were obtained on a high resolution 4800 TOF/TOF mass spectrometer with Voyager DE-STR. Thermal analysis (TGA) was performed on a TA Instruments TGA 2100 thermogravimetric analyzer under purified nitrogen at a heating rate of $10{ }^{\circ} \mathrm{C} \mathrm{min}^{-1}$. Differential scanning calorimetry (DSC) was conducted under nitrogen on a TA Instruments 2100 DSC. The sample was heated at $10^{\circ} \mathrm{C} \mathrm{min}^{-1}$ from 25 to $225{ }^{\circ} \mathrm{C}$. UV-vis absorption spectra were recorded by using a Cary 5000 UV-vis-near-IR double beam spectrophotometer. Photoluminescence (PL) spectra were obtained with a FP-6500 (JASCO). Cyclic voltammetry (CV) was carried out by using a PowerLab/AD instrument model system in a $0.1 \mathrm{M}$ solution of tetrabutylammonium hexafluorophosphate $\left(\mathrm{Bu}_{4} \mathrm{NPF}_{6}\right)$ at a scan rate of $50 \mathrm{mV} \mathrm{s}^{-1}$ in anhydrous acetonitrile as the supporting electrolyte. A glassy carbon disk $\left(\sim 0.05 \mathrm{~cm}^{2}\right)$ coated with a thin small molecule film, an $\mathrm{Ag} / \mathrm{AgCl}$ electrode, and a platinum wire were used as the working electrode, reference electrode, and counter electrode, respectively. Density functional theory (DFT) calculations were carried out at the B3LYP/6-31G* level of theory by using the Spartan 08 computational suite. Atomic force microscopy (AFM) (Multimode IIIa, Digital Instruments) was performed in tapping mode to obtain surface images (surface area: $5 \times 5 \mu^{2}$ ) of the small molecule: $\mathrm{PC}_{71} \mathrm{BM}$ blend films processed with and without DIO under ambient conditions.

\section{Fabrication and characterization of the solar cell devices}

The devices were fabricated with the conventional structure glass/ITO/PEDOT : PSS/active layer (DMF-BP-T-MMN : PC $_{71^{-}}$ $\mathrm{BM} / \mathrm{LiF} / \mathrm{Al}$ by using a solution process. The ITO-coated glass substrates were cleaned by washing in detergent, deionized water, acetone, and isopropyl alcohol under ultrasonication for 20 min each and subsequently dried with a nitrogen blower. A thin layer $(\sim 40 \mathrm{~nm})$ of PEDOT : PSS (Clevios P VP AI 4083, filtered at $0.45 \mu \mathrm{m}$ PVDF) was spin-coated at $4000 \mathrm{rpm}$ onto the ITO surface. After baking the substrates at $120{ }^{\circ} \mathrm{C}$ for $20 \mathrm{~min}$, they were transferred into a nitrogen-filled glovebox. Subsequently, the active layer was spin-coated from donor-acceptor blend solutions with various ratios and total concentrations, and with different volume fraction of the additive 1,8-diiodooctane. Finally, a $0.8 \mathrm{~nm} \mathrm{LiF}$ layer and a $80 \mathrm{~nm}$ Al layer were deposited onto the active layer under high vacuum $\left(2 \times 10^{-6}\right.$ torr). The effective area of each cell was $9 \mathrm{~mm}^{2}$ as defined by the mask. The current density-voltage $(J-V)$ characteristics of the photovoltaic devices were measured under ambient conditions by using a Keithley Model 2400 source-measurement unit. An Oriel xenon lamp $(450 \mathrm{~W})$ with an AM1.5 G filter was used as the solar simulator. The light intensity was calibrated to $100 \mathrm{~mW}$ $\mathrm{cm}^{-2}$ by using a calibrated silicon cell with a KG5 filter, which is traced to the National Renewable Energy Laboratory (LREL). The external quantum efficiency (EQE) spectra were obtained by using a photomodulation spectroscopic set-up (model Merlin, Oriel), a calibrated Si UV detector, and a SR570 low noise current amplifier.

\section{Hole mobility measurements}

Hole-only devices were fabricated with the configuration ITO/ PEDOT : PSS/DMF-BP-T-MMN : $\mathrm{PC}_{71} \mathrm{BM} / \mathrm{Au}$. The $\mathrm{Au}$ layers was deposited at a low speed (1/s) to prevent the penetration of $\mathrm{Au}$ atoms into the active layers. The active layers were spin-coated with or without DIO (2 vol\%). The mobilities were extracted by fitting the current-voltage curves with the Mott-Gurney relationship (space charge limited current): 


$$
J=\frac{9}{8} \varepsilon_{0} \varepsilon_{\mathrm{r}} \mu_{\mathrm{h}} \frac{V^{2}}{L^{3}}
$$

where $J$ is the current density, $L$ is the film thickness of the active layer, $\mu_{\mathrm{h}}$ is the hole mobility, $\varepsilon_{\mathrm{r}}$ is the relative dielectric constant of the transport medium, $\varepsilon_{0}$ is the permittivity of free space, $V$ is the internal voltage of the device, and $V=V_{\text {appl }}-V_{\mathrm{r}}-$ $V_{\mathrm{bi}} V_{\text {appl }}$ is the applied voltage to the device, $V_{\mathrm{r}}$ is the voltage drop due to contact resistance and series resistance across the electrodes, and $V_{\mathrm{bi}}$ is the built-in voltage due to the difference between the work functions of the two electrodes. $V_{\mathrm{bi}}$ can be determined from the transition between the ohmic region and the SCLC region.

\section{Acknowledgements}

This study was supported by a grant from the National Research Foundation of Korea (NRF), funded by the Korean Government (MSIP NRF-2014R1A2A1A05004993), and by the New \& Renewable Energy Technology Development Program of KETEP (20113020010070). This research was also supported by the Chung-Ang University Research Scholarship Grants in 2013.

\section{Notes and references}

1 S. Gunes, H. Neugebauer and N. S. Sariciftci, Chem. Rev., 2007, 107, 1324.

2 Y.-J. Cheng, S.-H. Yang and C.-S. Hsu, Chem. Rev., 2009, 109, 5868.

3 J. Jo, A. Pron, P. Berrouard, W. L. Leong, J. D. Yuen, J. S. Moon, M. Leclerc and A. J. Heeger, Adv. Energy Mater., 2012, 2, 1397.

4 G. Li, R. Zhu and Y. Yang, Nat. Photonics, 2012, 6, 153.

5 H. Zhou, L. Yang and W. You, Macromolecules, 2012, 45, 607.

6 L.-M. Chen, Z. Hong, G. Li and Y. Yang, Adv. Mater., 2009, 21, 1434.

7 B. Walker, C. Kim and T.-Q. Nguyen, Chem. Mater., 2011, 23, 470.

8 O. P. Lee, A. T. Yiu, P. M. Beaujuge, C. H. Woo, T. W. Holcombe, J. E. Millstone, J. D. Douglas, M. S. Chen and J. M. J. Fréchet, Adv. Mater., 2011, 23, 5359.

9 Y. Sun, G. C. Welch, W. L. Leong, C. J. Takacs, G. C. Bazan and A. J. Heeger, Nat. Mater., 2012, 11, 44.

10 J. A. Love, C. M. Proctor, J. Liu, C. J. Takacs, A. Sharenko, T. S. van der Poll, A. J. Heeger, G. C. Bazan and T.-Q. Nguyen, Adv. Funct. Mater., 2013, 23, 4990.

11 Y. Liu, L. Ma, Y. Li, Y. Liu, D. Zhu and X. Zhan, Adv. Energy Mater., 2013, 3, 1166.

12 H.-Y. Lin, W.-C. Huang, Y.-C. Chen, H.-H. Chou, C.-Y. Hsu, J. T. Lin and H.-W. Lin, Chem. Commun., 2012, 48, 8913.

13 J. Zhou, Y. Zuo, X. Wan, G. Long, Q. Zhang, W. Ni, Y. Liu, Z. Li, G. He, C. Li, B. Kan, M. Li and Y. Chen, J. Am. Chem. Soc., 2013, 135, 8484.

14 Y. Liu, C.-C. Chen, Z. Hong, J. Gao, Y. (Michael) Yang, H. Zhou, L. Dou, G. Li and Y. Yang, Sci. Rep., 2013, 3, 3356.
15 Y. Chen, X. Wan and G. Long, Acc. Chem. Res., 2013, 46, 2645. 16 A. Mishra and P. Bäuerle, Angew. Chem., Int. Ed., 2012, 51, 2020.

17 J. Roncali, P. Leriche and P. Blanchard, Adv. Mater., 2014, 23, 3821.

18 H. Wang, F. Liu, L. Bu, J. Gao, C. Wang, W. Wei and T. P. Russell, Adv. Mater., 2013, 25, 6519.

19 J. Zhang, L. Yang, M. Zhang and P. Wang, RSC Adv., 2013, 3, 6030.

20 J. Liu, Y. Sun, P. Moonsin, M. Kuik, C. M. Proctor, J. Lin, B. B. Hsu, V. Promarak, A. J. Heeger and T.-Q. Nguyen, Adv. Mater., 2013, 25, 5898.

21 A. Sutter, P. Retailleau, W.-C. Haung, H.-W. Lin and R. Ziessel, New J. Chem., 2014, 38, 1701.

22 T. M. Clarke and J. R. Durrant, Chem. Rev., 2010, 110, 6736. 23 S.-C. Lo and P. L. Burn, Chem. Rev., 2007, 107, 1097.

24 J. H. Delcamp, A. Yella, T. W. Holcombe, M. K. Nazeeruddin and M. Grätzel, Angew. Chem., Int. Ed., 2013, 52, 376.

25 H.-W. Lin, J.-H. Chang, W.-C. Huang, Y.-T. Lin, L.-Y. Lin, F. Lin, K.-T. Wong, H.-F. Wang, R.-M. Ho and H.-F. Meng, J. Mater. Chem. A, 2014, 2, 3709.

26 G. He, Z. Li, X. Wan, J. Zhou, G. Long, S. Zhang, M. Zhang and Y. Chen, J. Mater. Chem. A, 2013, 1, 1801.

27 Y. Li, K. Yao, H.-L. Yip, F.-Z. Ding, Y.-X. Xu, X. Li, Y. Chen and A. K.-Y. Jen, Adv. Funct. Mater., 2014, 24, 3631.

28 Y. J. Kim, K. H. Park, J.-j. Ha, D. S. Chung, Y.-H. Kim and C. E. Park, Phys. Chem. Chem. Phys., 2014, 16, 19874.

29 P. Dutta, W. Yang, S. H. Eom, W.-H. Lee, I. N. Kang and S.-H. Lee, Chem. Commun., 2012, 48, 573.

30 T. Ameri, P. Khoram, J. Min and C. J. Brabec, Adv. Mater., 2013, 25, 4245.

31 L. Fu, W. Fu, P. Cheng, Z. Xie, C. Fan, M. Shi, J. Ling, J. Hou, X. Zhan and H. Chen, J. Mater. Chem. A, 2014, 2, 6589.

32 K. DO, C. Kim, K. Song, S. J. Yin, J. K. Lee and J. Ko, Sol. Energy Mater. Sol. Cells, 2013, 115, 52.

33 L. Dou, J. You, J. Yang, C.-C. Chen, Y. He, S. Murase, T. Moriarty, K. Emery, G. Li and Y. Yang, Nat. Photonics, 2012, 6, 180.

34 T. S. van der Poll, J. A. Love, T.-Q. Nguyen and G. C. Bazan, Adv. Mater., 2012, 24, 3646.

35 Q. Shi, P. Cheng, Y. Li and X. Zhan, Adv. Energy Mater., 2012, $2,63$.

36 Q. Peng, X. Liu, Y. Qin, D. Zhou and J. Xu, J. Polym. Sci., Part A: Polym. Chem., 2011, 49, 4458.

37 J. D. Zimmerman, X. Xiao, C. K. Renshaw, S. Wang, V. V. Diev, M. E. Thompson and S. R. Forrest, Nano Lett., 2012, 12, 4366.

38 R. Shivanna, S. Shoaee, S. Dimitrov, S. K. Kandappa, S. Rajaram, J. R. Durrant and K. S. Narayan, Energy Environ. Sci., 2014, 7, 435.

39 S.-H. Hwang, Y. K. Kim, Y. Kwak, C.-H. Lee, J. Lee and S. Kim, Synth. Met., 2009, 159, 2578. 